\title{
The public health importance of the association between Componotus Consobrinus and potential bacterial pathogens in human dwellings
}

\begin{abstract}
Camponotus consobrinus, the banded sugar ant is so called because of its liking for sweet food. This study was carried out to determine the association between Camponotus consobrinus and potential bacterial pathogens in human dwellings and their public health importance. The ants were purposively collected from four locations; kitchens, bed rooms of various homes, shops and bakeries. Out of the 250 Camponotus consobrinus caught for the study, $90(36.0 \%)$ were caught in the kitchen, $75(30.0 \%)$ in the bed rooms $40(16.0 \%)$ in the bakery while $45(18.0 \%$ ) were caught in the shops. A prevalence of $82.0 \%$ microbial isolates was recorded in the study. The kitchen had the highest number of isolates was $75(36.6 \%)$ followed by the bed room $55(26.8 \%)$ while the bakery recorded the lowest number of isolates $35(17.1 \%)$. Escherichia coli was the most common isolate $73(30.0 \%)$, followed by Morganella morganii 45(18.0\%) while Serratia marcescens and Citrobacter freundii were the lowest common isolates $10(4.0 \%)$ each. Most of the Compnotous consobrinus examined in the four locations harboured potential pathogens. The presence of ants in homes and shops may lead to the spread of pathogenic microorganisms. Therefore, the control of ants in human dwellings must be taken seriously.
\end{abstract}

Keywords:Componotus consobrinus, Microbial pathogens, Transmission, Public health
Volume 5 Issue 7 - 2017

\author{
Ofonime M Ogba,' Augustine A Akpan,' \\ Oluwayemisi A Olorode, ${ }^{2}$ Iquo B Otu \\ Bassey \\ 'Department of Medical Laboratory Science, University of \\ Calabar, Nigeria \\ ${ }^{2}$ Department of Pharmaceutical Microbiology and \\ Biotechnology, Niger Delta University, Nigeria
}

\begin{abstract}
Correspondence: Gazmore Bardhi, Radiotherapy Institute of Oncology QKUK, Prishtine, Kosova, Mati I Objekti, CI5//8 K-V-N22, Europe, Tel 38949893366,
\end{abstract}

Email gazmore@hotmail.com

Received: September II, 2017| Published: November 30, 2017
Abbreviations: CLED, Cysteine Lactose Electrolyte Deficient; SAB, Sabouraud Dextrose Agar; KIA, Kligler Iron Agar

\section{Introduction}

Camponotus consobrinus, the banded sugar ant is a species in the ant family Camponotus. The ant is so called because of its liking for sweet food and the orange-brown band that goes round its gaster. ${ }^{1}$ Ants are insects found in households, shops, hospitals and food service establishment. They are a nuisance when they occupy residence, restaurants and other places where food is prepared or eaten, yet they are considered as harmless small creatures. ${ }^{2,3}$

Componotus consobrinus is known as Nwanwaefudabang in Efik and Ibibio language the most spoken in Calabar. The banded sugar antsexist in different forms, measuring between 5 to 15 millimeters in length, making them a large species. ${ }^{4}$ Their colonies harbor two types of workers; major and minor workers with different size ranges. The male ants are completely black in colour while the females possess black heads, orange thorax and the orange-brown band round their gaster. $^{5}$

Banded sugar ants are noctornal. They also damage furniture and fittings with their mandibles. ${ }^{6}$ Ants in general are potential mechanical vectors of bacteria such as Escherischia coli, Shigella, Salmonella, Enterobacter and Staphylococcus species, etc.7,8 Ants can crawl on human secretions and waste such as urine, faces and sputum, transmitting microorganisms to utensils and surfaces in general. ${ }^{3}$

These ants are picked out of human foods on the dining table without fear of contamination by microbes. Nevertheless, little is known about their potential for carrying and transmitting pathogenic bacteria in households, and food related facilities. Many people live with and allow ants in their homes without any knowledge of the public health implication and possible pathogens that these insects carry. The level of microbial carriage of Camponotus consobrinus in association to the environment in which they are found is not known.
Urbanization processes results in challenges such as unusual population growth, poorly implemented sanitary control measures and water contamination. These scenario may promote the dissemination of arthropods and therefore of the diseases they transmit. For this reason, the presence of ants in human dwellings could be hazardous to health. ${ }^{9,10}$ Ants have impressive mobility features, reaching speeds of $3 \mathrm{~cm} / \mathrm{s}$. This advantage grants these insects access to several environments, carrying pathogenic microorganisms that pose potential health threats. ${ }^{11}$ The social organization of ants also induces workers to roam around several home environments. In this process these insects may acquire bacteria in potentially contaminated environments like bathrooms, toilets, stores, kitchens etc. The presence of pathogenic bacteria in the tegument of ants foraging in human dwellings qualify them as potentially important agents in the spread of infectious diseases. ${ }^{10}$

Oliveira et al. ${ }^{12}$ in their study in Bahia, Brazil reported that, ants were carriers of pathogenic bacteria and may transmit the pathogens directly, when they crawl up a patient's skin, or indirectly, when they run on objects. They also reported high resistance to selected antimicrobials among the isolates from the ants which is a concern in this era of antimicrobial resistance war. With the growing concern about the presence of ant in human environments. It is necessary to know if banded sugar ants could transmit pathogenic organisms to man. This study was carried out to determine the potential pathogenic microbial profile on the external body parts of banded sugar ant collected from bakeries, shops and kitchen of different homes located in Calabar South Local Government Area of Cross River State.

\section{Materials and methods}

\section{Study area/sites}

The study was carried out in Calabar South Local Government area of Cross River State. Calabar was the first capital city of Nigeria. She is located at latitude $04^{\circ} \mathrm{N}$ and longitude $80^{\circ} 10^{\circ} \mathrm{E}$ along the 
coastal plains of Nigeria. ${ }^{13}$ Calabar is also known as the paradise city and has a great tourism potential. She has recreational centers like the Museum, Cultural center, Tinapa, and a Seaport. ${ }^{13}$ Camponotus consobrinus were purposively collected from three sampling sites in Calabar south local government area. The locations were; kitchens, Bed rooms and sitting rooms of various homes, grocery/food Shops and Bakeries. The homes, shops and bakeries where the ants were collected were made of brick walls some of which had cracks that could serve as nests to ants. They also had wooden furniture example, kitchen cabinets, chairs, wardrobes etc where the ants could nest in. The kitchens, food shops and bakeries were selected because ants are attracted to sweet foods including proteins and carbohydrates.

\section{Sample collection}

A total of 250 banded sugar ants were collected from homes, shops and bakeries within Calabar South Local Government Area. The ants were obtained between the months of May to October, 2016. This covered both rainy and dry seasons which are the two seasons in Nigeria. The rainy season spans between April to September, while the dry season is between October to March. The ants are seen in human dwellings in the two seasons in Calabar. The sample collection took place within the hour of $6: 30 \mathrm{pm}$ to $11: 00 \mathrm{pm}$. The ants were trapped in transparent plastic containers with baits including:sugar, pineapple peals and sugar cane syrup. The ants were removed and put in $10 \mathrm{mls}$ of peptone water in sterile universal bottles and pooled as 5 per universal bottle. The containers were vigorously shaken to wash the external surface of the ant. It was left overnight and transported to Microbiology laboratory, University of Calabar Teaching Hospital for analysis.

\section{Sample processing}

Culture:A loopful of overnight pooled broth containing 5 ants per sample bottle was cultured on Chocolate agar, Cysteine Lactose Electrolyte Deficient agar (CLED) and Sabouraud dextrose agar (SAB). Plates were incubated aerobically at $370 \mathrm{C}$ for 24 hours. After incubation period, the plates were checked for microbial growth. ${ }^{14}$ Pure cultures of isolates were obtained by sub-culture individual isolates onto cysteine lactose electrolyte deficient (CLED) agar and nutrient agar. Plates were incubated for 24 to 48 hours until colonies were visible. ${ }^{15}$

Identification of isolates:Isolates were identified morphologically and through biochemical tests. Gram staining, urease test, coagulase test, catalase, sugar fermentation on Kligler iron agar (KIA) were Indole test were carried out. ${ }^{15,16}$

\section{Data analysis}

Data were analyzed using Epi Info 2012 (CDC, Atlanta, Georgia, USA) statistical software. Descriptive statistics were carried out. Frequencies were calculated for categorical variables. Interactions between specific categorical clinical variables were tested for significance using the $\chi^{2}$ test. A p-value of $\leq 0.05$ was considered statistically significant.

\section{Results}

Figure 1 shows the distribution of Camponotus consobrinus by location of catch. Out of the 250 Camponotus consobrinus caught for the study, 90(36.0\%) were caught in the kitchen, 75(30.0\%) in the bed rooms while $45(18.0 \%)$ were caught in the shops. Table 1 shows the profile of micro-organisms associated with Camponotus consobrinus in households sampled. A total of 205 bacterial and fungal species were isolated from the Banded sugar ants, Escherichia coli was the most common isolate 75(30.0\%), followed by Morganella morganii $45(18.0 \%)$ while Serratia marcescens and Citrobacter freundii were the lowest common isolates $10(4.0 \%)$ each. Table 2 shows the distribution of microbial isolates associated with the external surface of Camponotus consobrinus by location of catch. Out of the 250 Camponotus consobrinus sampled in the four locations $82.0 \%$ prevalence of different microbial isolates was recorded in the study. The kitchen had the highest number of isolates $75(36.6 \%)$ followed by the bed room 55(26.8\%) while the bakery recorded the lowest number of isolates $35(17.1 \%)$. The most common bacterial isolate in the study was Escherichia coli with $33.3 \%, 45.4 \%$ and $62.5 \%$ prevalence in the kitchens, bed rooms and shops respectively (Table 2).

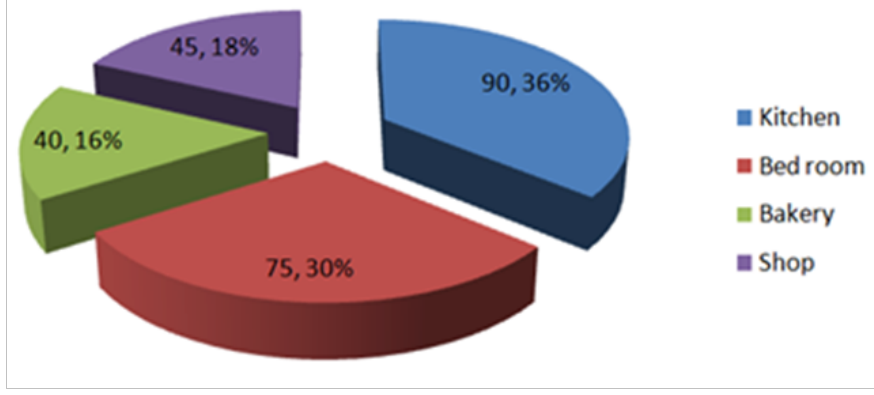

Figure I The photograph of adult Camponotus consobrinus showing the different parts.

The distribution of Camponotus consobrinus by location of catch.

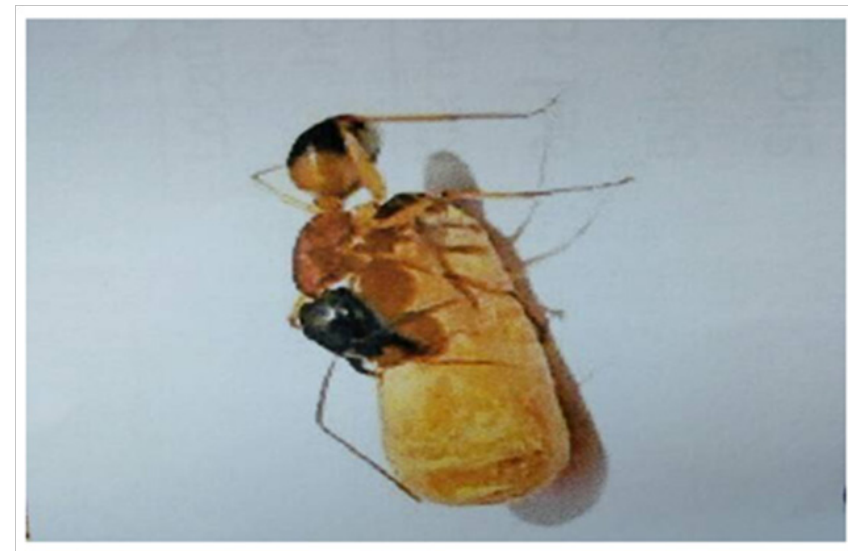

Figure 2 Camponotus consobrinus on a food particle.

Table I Profile of Micro-organisms associated with Camponotus consobrinus in households

\begin{tabular}{ll}
\hline Microbial isolates & No. $(\%)$ isolates \\
\hline Escherichia coli & $75(30.0)$ \\
Morganella morganic & $45(18.0)$ \\
Staphylococcus aureus & $20(8.0)$ \\
Candida spp & $25(10.0)$ \\
Klebsiella spp & $20(8.0)$ \\
Serratia marcescens & $10(4.0)$ \\
Citrobacter fraundii & $10(4.0)$ \\
Total & 205 \\
\hline
\end{tabular}


Table 2 Distribution of microbial isolates on Camponotus consobrinus by location of catch

\begin{tabular}{|c|c|c|c|c|c|}
\hline \multirow{2}{*}{ Microbial isolates } & \multicolumn{5}{|c|}{ Location of catch/No. (\%) isolates } \\
\hline & Kitchens $(n=90)$ & Bed rooms $(n=75)$ & Bakery $(n=40)$ & Shops $(n=45)$ & Total \\
\hline Escherichia coli & $25(33.3)$ & $25(45.4)$ & $0(0.0)$ & $25(62.5)$ & $75(36.6)$ \\
\hline Morganella morganii & $15(20.0)$ & $0(0.0)$ & $30(91.4)$ & $0(0.0)$ & $45(21.9)$ \\
\hline Staphylococcus aureus & $5(6.7)$ & $10(18.1)$ & $5(14.3)$ & $0(0.0)$ & $20(9.7)$ \\
\hline Candida spp & $15(20.0)$ & $0(0.0)$ & $0(0.0)$ & $5(12.5)$ & $20(9.7)$ \\
\hline Klebsiella spp & $10(13.3)$ & $5(9.1)$ & $0(0.0)$ & $5(12.5)$ & $20(9.7)$ \\
\hline Citrobacter freundii & $0(0.0)$ & $10(18.1)$ & $0(0.0)$ & $0(0.0)$ & $10(4.8)$ \\
\hline Total & $75(36.6)$ & $55(26.8)$ & $35(17.1)$ & $40(19.5)$ & $205(82.0)$ \\
\hline
\end{tabular}

n, number of Camponotus consobrinus examined.

Out of the 75(36.6\%) microbial isolates encountered in the kitchen among ants Escherichia coli was the most prevalent 33.3\%, followed by Morganella morganii 15(20.0\%) and Candida species respectively. However, the least encountered isolates among kitchen ants were Staphylococcus aureus 5(6.7\%) and Serratia marcescens 5(6.7\%) respectively (Table 2). The most encountered isolates in the bed rooms was also Escherichia coli $45.4 \%$ followed by Staphylococcus aureus $18.1 \%$ and Citrobacter freundii $18.1 \%$ respectively. Morganella morganii was also the most common isolate $91.4 \%$ in the bakery (Table 2).

\section{Discussion}

The occurrence of ants in households and the risks associated with these insects has been a research focus, ${ }^{6}$ but little or no work is done in households or other premises on the bacterial carriage of these insects and the risk they could pose to occupants of such households. In this study most of the banded sugar ants were caught in the kitchen $90(36.0 \%)$ and bed rooms $75(30.0 \%)$. This reveals the possibility of transmission of potential food pathogens example Escherichia coli into foods not properly protected or covered in the kitchen. Fontana et al. ${ }^{17}$ reported that.

Camponotus consobrinus is a potential agent for disease transmission.

Among the factors that may favour the presence of ants in the kitchen and bedrooms are; attraction to food scraps, organic materials, clothing, objects that may contain ant nests and unhygienic environments. Although we did not investigate these factors Zarzuela et al. ${ }^{18}$ \& Braganca et al. ${ }^{19}$ also reported that clothing materials as possible nests to house hold ants.

In this study a total of 205 bacterial and fungal species were isolated from the Banded sugar ant's integuments. Escherichia coli were the most common isolates 75(30.0\%), followed by Morganella morganii $45(18.0 \%)$. This is different from the work of Maximo et al. ${ }^{6}$ in Brazil, where Bacillus spp. $45.7 \%$ and Listeria spp. $(10 \%)$ were the most prevalent. The difference in the types of isolates may be due to geographical differences. Other bacteria encountered in our study were Staphylococcus aureus 20(8.0\%), Klebsiella species 20(8.0\%), with Serratia marcescens and Citrobacter freundii being the lowest common isolates $10(4.0 \%)$ each. Other bacteria associated with Maximo \& colleagues' ${ }^{9}$ study were Pseudomonas aeruginosa, Streptococcus species, Klebsiella species, Staphylococcus aureus, Arcanobacterium species, Proteus species, Micrococcus luteus and Staphylococcus epidermidis. There is a slight difference in the bacterial profile of the two studies, although both contain potential human pathogens. The bacterial profile in our study reveals that most of the isolates were potential pathogens to humans. In this study
Candida albicans species was also isolated. It has been reported as the most prevalent opportunistic fungal agent in our locality Ogba et al. ${ }^{20}$ Its presence in our environment may explain the reason for cross infection among subjects.

\section{Conclusion}

Most of the Compnotus consobrinus examined in the four locations harboured potential pathogens. Our result is of public health importance because the presence of ants in homes and shops may lead to the spread of pathogenic microorganisms. Therefore, the control of ants in human dwellings must be taken seriously.

\section{Acknowledgements}

We acknowledge the University of Calabar Teaching Hospital for the use of their facility.

\section{Ethical approval}

Not applicable.

\section{Competing interests}

Authors have declared that no competing interests exist.

\section{Source of funding}

None.

\section{References}

1. Lima WR, Marques G, Rodrigues FS. Ants in a hospital environment and their potential as mechanical bacterial vectors. Rev Soc Bras Med Trop. 2013;46(5).

2. Hockings DF. Pests, diseases and beneficial:friends and foes of Australian gardens. Collingwood, Victoria:CSIRO publishing, Australia, 2014;pp. 272

3. Pai WW, Chen WC, Peng CF. Isolation of non-tuberculoses mycobacteria from hospital cockroaches. J Hosp Infec. 2013;53(3):224-228.

4. https://australianmuseum.net.au/sugar-ant.

5. Orr MR, Dahlsten Donald L, Benson WW. Ecological interactions among ants in the genus linepithema, their phorid parasitoids, and ant competitors. Ecological Ecology. 2003;28(2):203-210.

6. Heros JM, Henrique LF, Marcela C, et al. Ants as vectors of pathogenic microorganisms in a hospital in Sao Paulo Country, Brazil. BMC Res Notes. 2014;7:554.

7. Onyido AE, Nwangwu UC, Aribodor DN, et al. Bacterial pathogens associated with wild-caught houseflies in Awka Metropololis. IOSR Journal of Pharmacy and Biological Sciences (IOSR-JPBS). 2012;6(1):12-19. 
8. Rodriguez PLC, Florez CVM, Russo A, et al. The Ghost ant Tapinoma melanocephalum (formicidae) as mechanical vector of clinical important bacteria. 2016.

9. Freitas MR, Teixeira IRV. A formiga fantasma (Tapinoma Melanocephalum) domina os ambientes hospitalares em Guaxupé, MG. Sociedade de Ecologia do Brasil, Caxambu, Brazil, 2007;p. 1-2.

10. Pesquero MA, Elias Filho J, Carneiro LC, et al. Formigas em ambiente hospitalar e seu potencial como transmissoras de bactérias. Neotrop Entomol. 2008;37(4):472-477.

11. Tanaka IT, Viggiani AMFS, Person OC. Bactérias veiculadas por formigas em ambiente hospitalar. Arquivos Médicos do $A B C$. 2007;32(2):60-63

12. Oliveira BRM, de Sousa LF, Soares RC, et al. Ants as Vectors of Bacteria in Hospital Environments. J Microbiology. 2017;7(1):1-7.

13. National Population Commission. National census, Cross River State, Nigeria, 2006.

14. Ogba OM, Olorode OA, Adie GA. Bacterial pathogens associated with wound infections in Calabar, Nigeria. Mary Slessor Journal of Medicine. 2014;13(1):26-33
15. Ochei J, Kolhatkar A. Medical laboratory science theory and practice. 2007;pp. 835-843.

16. Cheesbrough M. District laboratory practice in tropical countries. 2000;pp. 62-69.

17. Fontana R, Wetler RMDC, Aquino RSS, et al. Pathogenic bacteria dissemination by ants (Hymenoptera:Formicidae) in two hospitals in northeast Brazil. Neotrop Entomol. 2010;39(4):655-663.

18. Zarzuela MFM, Pacheco LB, Campos Farinha AEC, et al Avaliação do potencial das formigas como vetores de bactérias em ambientes residenciais e cozinhas semi-industriais. Arq Inst Biol. 2002;69(Suppl):1-306.

19. Bragança MAL, Lima JD. Composição, abundância e índice de infestação de espécies de formigas em um hospital materno-infantil de Palmas, TO. Neotrop Entomol. 2010;39(1):124-130.

20. Ogba OM, Olorode OA, Eyo AO, et al. Antifungal Susceptibility Testing of Candida Isolated from HIV/AIDS Patients presenting with Lower Respiratory Tract Infections. IJMPS. 2015;5(10):1-4 